УДК 342.9:347.961

DOI https://doi.org/10.32837/pyuv.v0i5(34).659

\author{
A. B. Кудін \\ orcid.org/0000-0002-3259-454X \\ здобувач \\ Науково-дослідного інституту публічного права
}

\title{
ПАТЕНТ ЯК ОБ’ЄКТ АДМІНІСТРАТИВНО-ПРАВОВОЇ ОХОРОНИ В УКРАЇНІ
}

Актуальність теми. Охорона та захист прав, свобод і законних інтересів особи є пріоритетним напрямом демократичної соціальної держави, оскільки права і свободи людини та їх гарантії визначають зміст і спрямованість діяльності держави, яка відповідає перед людиною за свою діяльність. Утвердження і забезпечення прав і свобод людини є головним обов'язком держави [6].

Однією з основних функцій виконавчої влади у будь-якій державі є функція адміністративно-правової охорони прав, свобод та законних інтересів фізичних і юридичних осіб. Особливе значення має те, що сьогодні значного осмислення потребує співвідношення інтересів держави та інтересів громадян, виконання органами виконавчої влади їхніх функцій на якісно новому рівні, що відповідає вимогам сьогодення. Зазначене спонукає науковців до пошуку ефективних та якісно нових шляхів урегулювання адміністративних відносин, уточнення понять, сутності й значення основних правових категорій, розробки стандартів виконання органами виконавчої влади функцій держави з охорони прав, свобод та законних інтересів громадян [7, с. 66-67].

Огляд останніх досліджень. Проблемні питання патентної діяльності досліджували такі вчені, як Г. Андрощук, В. Бурячок, Є. Валькова, М. Галянтич, С. Головань, І. Запорожець, С. Золота, I. Каплун, О. Коротун, І. Кравченко, К. Куркова, А. Пишна, В. Понікаров, Г. Римарчук, Д. Смерницький, О. Тандир, Є. Юркова та інші. При цьому комплексних досліджень патентування як об’єкту адміністративного регулювання в Україні, на жаль, замало, що комплексно обгрунтовуе актуальність обраної теми статті.

Мета статті полягає в тому, щоб на основі системного аналізу норм законодавства, позицій вчених-адміністративістів та науковців інтелектуального права, статистичної діяльності суб'єктів публічної адміністрації патентної діяльності визначити патент як об'єкт адміністративно-правової охорони в Україні.

Виклад основних положень. Щодо сутності розуміння «об'єкт», то С.Г. Стеценко об'єктом управління слушно вважає керований складник системи управління, те, на що спрямовано управління. До об'єктів управління він також відносить i процес виробництва, рослинний i тваринний світ, технічні пристрої та засоби [6, с. 41]. С.В. Ківалов та Л.Р. Біла під об'єктом адміністративних правовідносин розглядають те, заради чого виникають ці відносини, - поведінка, воля, свідомість, матеріальні цінності, нематеріальні блага тощо [5, с. 66].

A.I. Берлач стверджує, що об'єкт адміністративних правовідносин - це поведінка суб'єктів правовідносин, спрямована на забезпечення широкої сфери їх правових інтересів [1, с. 58].

Тобто об'єкт - це суспільна цінність, щодо якої суб'єкти права вступають у правовідносини та створюється система охорони.

Важливим для аналізу є формування сутності «патенту» як об'єкту правовідносин. Відповідно до законодавства, а саме Закону України «Про охорону прав на винаходи і корисні моделі" патент (патент на винахід, деклараційний патент на винахід, деклараційний патент на корисну модель, патент (деклараційний патент) на секретний винахід, деклараційний патент на секретну корисну модель) - охоронний документ, що засвідчує пріоритет, авторство і право власності на винахід (корисну модель) [12]. П.М. Цибульов вважає, що патент - це вид інтелектуальної (промислової) власності, який використовуються як інструмент, що регулює створення і передачу нових технологій [13]. Юридична енциклопедія Ю.С. Шемшученка визначає патент як виданий компетентним державним органом документ, що надає власнику виключне право на винахід (корисну модель) та являє собою форму охорони об'єктів інтелектуальної власності. Також в енциклопедії міститься думка про те, що патент потрібно розцінювати як підтвердження державою того, що дана пропозиція є винаходом (корисною моделлю) [14].

На наш погляд, патент - це правовизначальний документ права промислової власності, що отримується у встановленій законодавством процедурі з метою легітимізації патентної діяльності та підлягає правовій охороні як ціннісний об'єкт правовідносин.

Наступним є аналіз поняття «охорона». Великий тлумачний словник сучасної української мови тлумачить як: 1) оберігати від небезпеки кого, що-небудь, убезпечувати від загрози нападу, замаху і т. н.; 2) стояти на варті біля кого-, чогонебудь, вартувати, стерегти; 3) забезпечувати, 
гарантувати недоторканність кого-, чого-небудь; 4) оберігати від руйнування, знищення, завдавання шкоди; 5) захищати від чого-небудь [2, с. 825].

На думку у М.В. Вітрук, «охорона права» - це діяльність, спрямована на усунення перешкод у реалізації прав та обов'язків, на боротьбу з невиконанням обов'язків і зловживанням правами, на профілактику і попередження порушень прав та обов'язків, а засоби захисту застосовуються у разі невиконання обов'язку або зловживання правом та виникнення перешкод для їх здійснення чи існування суперечки про наявність самого права або обов'язку [3, с. 54].

М.О. Легенченко вказує, що термін «правова охорона" слід розглядати не тільки як установлення юридичних засобів, спрямованих на реалізацію суб'єктивного права та запобігання його порушенню, а й як правове регулювання правовідносин. Дійсно, норми про захист прав становлять лише певну частину охоронних норм, до яких належать запобігання порушенням i ті, що встановлюють імперативний механізм їх реалізації $[8$, с. 62$]$.

Отже, правова охорона за своєю юридичною природою є комплексною системою юридично-організаційних інструментів, засобів та процедур протидії посягань на певні правовідносини, що включає механізм відновлення порушених прав та накладення певних зобов'язань з метою припинення порушень правового регулювання у колі правовідносин.

Щодо сутності «адміністративно-правова охорона», то науковці В.В. Галунько та В.І. Олефір вважають, що адміністративно-правова охорона - це діяльність уповноважених органів публічної влади щодо профілактики правопорушень та відновлення порушених прав, свобод та законних інтересів фізичних і юридичних осіб, що здійснюються засобами адміністративного права з можливістю застосування заходів адміністративного примусу та здійснюється в трьох формах: правотворчій, коли створюються закони та підзаконні нормативно-правові акти; правозастосовній, коли втілюються в життя встановлені адміністративно-правові норми; правоохоронній, що включає засоби адміністративного впливу до порушників прав, свобод та законних інтересів фізичних і юридичних осіб [4, с. 76].

Своєю чергою адміністративно-правову охорону О.Ю. Салманова розглядає, враховуючи важливе значення охоронної функції, якою наділена правова система держави. Адже вона не тільки спрямована на запобігання порушенням нормальних процесів розвитку суспільних відносин у різноманітних сферах та усунення таких порушень, але й виступає як ефективний організуючий і забезпечувальний засіб [10, с. 25-26].

Аналізуючи таку правову категорію, як «адміністративно-правова охорона», I. Коросташова дійшла висновків, що в загальнотеоретичному значенні та в науці адміністративного права цю категорію варто розглядати в чотирьох аспектах, a саме як: 1) одну з функцій держави (правоохоронна функція); 2) завдання адміністративного права; 3) функцію адміністративного права; 4) діяльність органів державної влади, органів місцевого самоврядування, а також осіб, що надають публічні послуги. У першому випадку адміністративно-правова охорона розглядається як одна з внутрішніх функцій держави (правоохоронна функція), що розкриває ії соціальну сутність і призначення в суспільстві, оскільки адміністративне право є дієвим важелем втілення державою в особі уповноважених нею державних органів влади (публічної адміністрації), своєї регулятивної та охоронної ролі. У другому випадку адміністративно-правова охорона розглядається, як одне з основних завдань адміністративного права (як галузі права) щодо здійснення регулювання суспільних відносин управлінського характеру, які складаються у сфері управління й виконуються суб'єктами владних повноважень, внутрішньо-організаційній діяльності інших державних органів, а також у процесі здійснення громадськими організаціями, їхніми органами зовнішніх юридично-владних повноважень 3 метою реалізації завдань і функцій держави. У третьому - як функція адміністративного права, що полягає у здійсненні правової охорони прав, свобод і законних інтересів фізичних та юридичних осіб учасників адміністративних правовідносин (реалізується шляхом застосування спеціальних охоронних норм, а також діючих в охоронному режимі регулятивних (зобов'язуючих) норм. У четвертому випадку адміністративно-правова охорона - це система впорядкованої адміністративно-правовими нормами діяльності суб'єктів владних повноважень (публічної адміністраціі) [7, с. 71-72].

На наш погляд, адміністративно-правова охорона - це комплексна система владно-розпорядчих інструментів, засобів та процедур суб'єктів владних повноважень щодо протидії посяганням на конкретні ціннісні об'єкти правовідносин, що передбачають застосування заходів адміністративного примусу з метою відновлення порушених прав та засад правового регулювання у суспільній сфері.

На останок варто зазначити, про позицію П.М. Цибульової, яка вказує, що основним способом охорони права інтелектуальної власності $\mathrm{e}$ видача автору або іншому суб'єкту права об'єкта інтелектуальної власності охоронного документа - патенту чи свідоцтва. Вона називає чотири принципи правової охорони права інтелектуальної власності: 1) обороноспроможність, тобто коли об'єкт правової охорони повинен відповідати визначеним законом вимогам (наприклад, винахід відповідає умовам патентоспроможності, якщо він є новим, має винахідницький рівень 
і є промислово придатним); 2) визнання за правоволодільцем виключного права на об'єкт права інтелектуальної власності; 3) додержання прав не тільки правовласників, але й дійсних розробників (авторів, винахідників); 4) додержання балансу інтересів правовласника з одного боку і суспільства 3 іншого шляхом обмеження монополії на об’єкт права, наприклад, шляхом встановлення розумного строку дії охоронного документа [12].

Таким чином, у сфері адміністративно-правової охорони патент відіграє подвійну роль:

1) патент виступає як інструментальний спосіб адміністративно-правової охорони права промислової власності, адже легітимізує правові відносини патентної діяльності, створюючи для них систему правової охорони з метою попередження та припинення посягань і відновлення прав промислової власності як ціннісних об'єктів правового регулювання;

2) патент є ціннісним об’єктом адміністративно-правової охорони в Україні, адже суб'єкти владних повноважень через вчинення адміністративної діяльності охороняють конкретний, індивідуально-персоніфікований документ права промислової власності (патент), посягання на який зумовлює застосування заходів адміністративного примусу з метою захисту прав промислової власності, що нормативно закріплені цим патентом.

\section{Jimepamypa}

1. Берлач A.I. Адміністративне право України : навч. посіб. для дист. навч. Київ : Університет «Україна», 2005. $472 \mathrm{c}$.

2. Великий тлумачний словник сучасної української мови / уклад. і голов. ред. В. Т. Бусел. Київ, Ірпінь : Перун, 2005. 1728 с.

3. Витрук Н.В. Правовой статус личности в СССР. М. : Юрид. лит., 1985. 176 с.

4. Галунько В.В., Олефір В.І., Пихтін М.П. та інші. Адміністративне право України : навчальний посібник : у 2-х томах. Херсон : ПАТ «Херсонська міська друкарня» 2011. Т. 1 : Загальне адміністративне право. 320 с.

5. Ківалов С.В. Адміністративне право України : навч.-метод. посіб. Одеса : Юрид. л-ра, 2003312 с.

6. Конституція України від 28.06.1996 № $254 \kappa /$ 96-ВР. Відомості Верховної Ради України. 1996. № 30. Ст. 141.

7. Коросташова I.M. Адміністративно-правова охорона: загальнотеоретичні аспекти. Вісник Академї митної служби України. Серія: Право. 2015. № 2. C. $66-72$.

8. Легенченко М.О. Поняття охорони й захисту права та їх співвідношення. Актуальні проблели дер жави і права : зб. наук. пращь. Одеса : Юрид. л-ра, 2014. Вип. 72. С. 62-68.

9. Про охорону прав на винаходи і корисні моделі: Закон України від 15.12.1993 № 3687-XII. Відолості Верховної Ради України. 1994. № 7. Ст. 32.

10. Салманова О.Ю. Адміністративно-правові засоби забезпечення міліцією безпеки дорожнього руху : дис. ... канд.. юрид. наук : 12.00.07 "Адміністративне право і процес; фінансове право; інформаційне право» . Харків, 2002. 232 с.
11. Стеценко С.Г. Адміністративне право України : навч. посіб. Київ : Атіка, 2009. 624 с.

12. Цибульов П.М. Основи інтелектуальної власності : підруч. для студентів ВНЗ; Нац. ун-т «Одес. юрид. акад.». Київ : Видавн. дім Д. Бураго, 2014. 122 с.

13. Цибульов П.М. Введення до інтелектуальної власності: навчальний посібник. Київ: «Держ. інст. інтел. власн.», 2008. 124 с.

14. Юридична енциклопедія: В 6 т. / редкол.: Ю.С. Шемшученко (голова редкол.) та ін. Київ : «Укр. енцикл.», 1998. 1130 с.

\section{Анотація}

Кудін $A$. В. Патент як об'єкт адміністративно-правової охорони в Україні. - Стаття.

Актуальність статті полягає в тому, що охорона та захист прав, свобод і законних інтересів особи є пріоритетним напрямом демократичної соціальної держави, оскільки права і свободи людини та їх гарантії визначають зміст і спрямованість діяльності держави, яка відповідає перед людиною за свою діяльність. Утвердження і забезпечення прав і свобод людини є головним обов'язком держави. Мета статті полягає в тому, щоб на основі системного аналізу норм законодавства, позицій вчених-адміністративістів та науковців інтелектуального права, статистичної діяльності суб'єктів публічної адміністрації патентної діяльності, визначити патент як об'єкт адміністративно-правової охорони в Україні. В статті розкрито патент як ціннісний об'єкт адміністративно-правової охорони в Україні. Сформовано сутнісні поняття «правова охорона», «адміністративно-правова охорона», "патент». Визначено, що суб'єкти владних повноважень через вчинення адміністративної діяльності охороняють конкретний, індивідуально-персоніфікований документ права промислової власності (патент), посягання на який зумовлює застосування заходів адміністративного примусу з метою захисту прав промислової власності, що нормативно-закріплені цим патентом. Зроблено висновок, що у сфері адміністративно-правової охорони патент відіграє подвійну роль: 1) патент виступає як інструментальний спосіб адміністративно-правової охорони права промислової власності, адже легітимізує правові відносини патентної діяльності, створюючи для них систему правової охорони 3 метою попередження та припинення посягань і відновлення прав промислової власності як ціннісних об’єктів правового регулювання; 2) патент є ціннісним об'єктом адміністративно-правової охорони в Україні, адже суб'єкти владних повноважень через вчинення адміністративної діяльності охороняють конкретний, індивідуально-персоніфікований документ права промислової власності (патент), посягання на який зумовлює застосування заходів адміністративного примусу з метою захисту прав промислової власності, що нормативно-закріплені цим патентом.

Ключові слова: адміністративно-правове забезпечення, електронне врядування, інструменти, механізм, патент, патентна діяльність, принципи, публічна адміністрація, статус, суб’єкт.

\section{Summary}

Kudin A.V. Patent as an object of administrative and legal protection in Ukraine. - Article.

The relevance of the article is that the protection and defense of the rights, freedoms and legitimate interests of the individual is a priority of a democratic welfare state, as human rights and freedoms and their guarantees determine the content and direction of the state responsible to man for his activities. The establishment and protection 
of human rights and freedoms is the main duty of the state. The purpose of the article is to define a patent as an object of administrative and legal protection in Ukraine on the basis of a systematic analysis of legislation, positions of administrative scientists and scholars of intellectual law, statistical activities of public administration of patent activity. The article reveals the patent as a valuable object of administrative and legal protection in Ukraine. The essential concepts of "legal protection", "administrative and legal protection", "patent" are formed. It is determined that the subjects of power through the performance of administrative activities protect a specific, individualpersonalized document of industrial property rights (patent), encroachment on which leads to the application of administrative coercion to protect industrial property rights, which are regulated by this patent. It is concluded that in the field of administrative and legal protection the patent plays a dual role: 1) the patent acts as an instrumental method of administrative and legal protection of industrial property rights, because it legitimizes the legal relations of patent activity, creating a system of legal protection to prevent and stop encroachments, and the restoration of industrial property rights as valuable objects of legal regulation; 2) the patent is a valuable object of administrative and legal protection in Ukraine, because the subjects of power through the performance of administrative activities protect a specific, individually personified document of industrial property rights (patent), encroachment on which causes the application of administrative coercion to protect industrial property rights, which are regulated by this patent.

Key words: administrative and legal support, e-government, tools, mechanism, patent, patent activity, principles, public administration, status, subject. 